\title{
Monteiro Lobato e a metáfora das Cidades mortas
}

\author{
Tania Regina de Luca ${ }^{1}$
}

\author{
"São sempre as mesmas cartas, as mesmas obras e as mesmas informações, mas, por \\ milagre da paixão e da linguagem, quando cruzadas com seu contexto, as pesquisas \\ sugerem e condimentam apaixonadas polêmicas..."
}

Marisa Lajolo. Monteiro Lobato, um brasileiro sob medida

À Marisa, por seu contagiante entusiasmo e capacidade de reinvenção

O Vale do Paraíba, região Leste do Estado de São Paulo e que faz divisa com o Estado do Rio de Janeiro, constituiu-se em área pioneira do plantio do café. Ao crescimento e riqueza conhecidos a partir da segunda metade do século XIX, seguiu-se uma lenta e continua decadência, fruto da expansão dos cafezais para o oeste. As novas áreas não só dispunham de clima e solo mais adequados à rubiácea como foram ocupadas num momento em que o fim do regime de trabalho escravo era iminente, o que obrigou os fazendeiros a organizar a entrada de grandes levas de imigrantes. As crescentes distâncias das plantações em relação ao porto de Santos inviabilizavam, por sua vez, o transporte por tropas e exigiram a construção de uma intrincada malha ferroviária. No início do século XX, às cidades da porção paulista do Vale - Bananal, Silveiras, Areias, São José do Barreiro - só restavam lembranças de antigas glórias.

Trabalhos historiográficos específicos, levados a efeito partir de inventários e testamentos, álbuns de famílias, informações genealógicas, correspondências, diários e livros de anotações, têm contribuído para uma compreensão mais ampla acerca das práticas sociais e das estratégias políticas e econômicas imperantes numa sociedade organizada em torno do trabalho escravo e do capital mercantil, como era a do Vale do Paraíba. Exemplo marcante nesse sentido é a obra coletiva Resgate, uma janela para o oitocentos, ${ }^{2}$ escrita a partir da ampla e variada documentação do Comendador Manoel de Aguiar Vallim, conservada na fazenda Resgate, uma de suas propriedades em Bananal. O caso do Comendador, grande fazendeiro de café, dono de muitos escravos e um dos homens mais ricos do país quando de sua morte em 1878, permite aquilatar o enorme impacto representado pelo fim do tráfico de escravos em 1850, medida que condenou à extinção não apenas o regime de trabalho, mas a ordem que se erguera sob o solo da escravidão.

Em algumas décadas, a região do Vale do Paraíba transitou do fausto à decadência, processo que deve ter impressionado vivamente os contemporâneos. A própria morada da família Vallim e seu estilo de vida evidenciam a prosperidade do apogeu cafeeiro: as amplas sedes das fazendas com sua arquitetura neoclássica; o interior ricamente decorado, que incluía pinturas e ornamentos nas paredes e portas; a mobília sólida de mogno e os delicados lustres; os aparelhos de chá e demais louças, faqueiros, pratarias e castiçais, marcas de fidalguia essenciais para o bem receber e que distinguiam o ilustre pro- 
prietário. Luxo e conforto propiciado pelos lucros da exportação e que se repetia nas vivendas urbanas. Na segunda metade do XIX, o Vale povoou-se de imponentes fazendas e se nem todas ostentavam riqueza idêntica à do Resgate, a grande maioria deixava para trás a simplicidade dos tempos coloniais e acertava o passo com as novas tendências, tornando-se "verdadeiros monumentos neoclássicos em plena paisagem rural". ${ }^{3}$ Entretanto, o fim da escravidão, aliado ao deslocamento do café para áreas férteis e ainda inexploradas do Estado, implicou num verdadeiro colapso econômico, patente já no final do século XIX.

Em 1919, Monteiro Lobato publicou Cidades mortas, um conjunto de textos que tem sido tomado como retrato da região. A designação tornou-se famosa e ainda é usada para caracterizar o Vale do Paraíba, fato que até hoje muito incomoda os habitantes, que elaboraram uma memória extremamente negativa do escritor, como demonstrou o instigante trabalho de João Gabriel Rosa de Almeida. ${ }^{4}$

Nesse artigo pretende-se investigar os sentidos que a imagem cidades mortas assumiu nas explicações de Brasil construídas pelo escritor, o que obriga a ter em conta a sua trajetória pessoal, entendida a partir dos lugares que ocupou no campo intelectual; a história editorial do livro Cidades mortas e os significados que o mesmo foi assumindo em relação ao restante da obra lobatiana e à sua atuação dentro e fora do mundo letrado.

\section{Polêmicas em torno de Monteiro Lobato}

No campo intelectual brasileiro, poucas figuras têm dado margem a avaliações tão contraditórias quanto Monteiro Lobato, fato que pode ser relacionado às suas múltiplas atividades: contista; jornalista; crítico de arte; escritor infantil pioneiro; editor revolucionário; polemista; homem de ação e empresário que abraçou de forma apaixonada campanhas em prol da indústria do livro, do saneamento dos sertões, do ferro e do petróleo. Não falta quem o apresente como o símbolo mais acabado do nacionalismo e do patriotismo, tomados no seu sentido mais nobre, um lutador incansável pelo desenvolvimento do país, cuja recompensa foi amargar meses de prisão durante o Estado Novo de Getúlio Vargas (1937-1945). ${ }^{5}$

Outros acentuam sua atuação no mundo editorial e atribuem-lhe papel central na constituição de um campo intelectual brasileiro relativamente autônomo, para o que enfatizam seu empenho em alterar as práticas vigentes no mercado livreiro. Suas atividades editoriais remontam a meados de 1918, quando se tornou proprietário da Revista do Brasil, lançada em 1916 pelo grupo reunido em torno da redação do jornal O Estado de $S$. Paulo e que se constituía na principal publicação cultural da época, base a partir da qual Lobato organizou sua primeira editora, que faliu em 1925. Seu nome esteve associado a outros empreendimentos de grande vulto: a Companhia Editora Nacional, que organizou em 1926, e a Editora Brasiliense, da qual foi sócio na década de 1940. ${ }^{6}$

Tampouco faltam adjetivos elogiosos para sua produção infantil, que encantou seguidas gerações de brasileiros, seja por intermédio dos livros ou, mais recentemente, das várias adaptações para televisão das histórias da turma do Sítio do Pica-pau amare- 
lo. ${ }^{7}$ As personagens que criou seguem povoando a imaginação das crianças em episódios diários exibidos pela principal rede de televisão do país, além de comporem diversificada linha de produtos e brinquedos. Não por acaso, já se tentou avaliar quais teriam sido as possíveis influências exercidas por Monteiro Lobato sobre formas de apreensão do mundo, opiniões e atitudes compartilhadas por indivíduos que foram seus leitores. ${ }^{8}$

A unanimidade começa a claudicar quando o tema é a sua produção para adultos. Estabeleceu-se profundo fosso entre, por um lado, o modesto lugar que lhe é reservado na grande maioria das histórias literárias e, por outro, sua atuação no mundo letrado do início do século XX.

O escritor alcançou projeção a partir de 1914, por intermédio de dois artigos "Velha praga" e "Urupês" - publicados no jornal O Estado de S. Paulo, nos quais consubstanciou o personagem Jeca Tatu, caricatura ácida do trabalhador rural, tido como incapaz de evolução e avesso ao progresso. Sua correspondência revela que o tipo foi gestado lentamente, a partir da contingência que transformou em fazendeiro o doutor Monteiro Lobato, bacharel pela prestigiosa Faculdade de Direito do Largo São Francisco e impregnado pelas teorias raciais de Le Bon. ${ }^{9}$ A condição de proprietário de terras decadentes no Vale do Paraíba obrigou-o a conviver e relacionar-se cotidianamente com o caboclo, que não hesitou em taxar de baldio, seminômade, preguiçoso e fatalista.

A polêmica em torno do Jeca Tatu explica-se pelas características que lhe foram imputadas, todas na contramão da visão idílica que, não raro, romantizava o homem do campo e lhe atribuía dimensões épicas. Espécie de anti-herói nacional, a imagem incomodava por romper com o discurso ufanista a respeito do país e seus habitantes, além de trazer à tona questões sobre a permeabilidade do Brasil à modernização, os caminhos a serem trilhados para atingi-la, as causas e os responsáveis pelo nosso descompasso, de tal sorte que discutir o Jeca implicava em ter por objeto o país e seus dilemas. ${ }^{10}$

Contudo, não menos impactante era a forma, marcada pelo manejo inovador do léxico, o entremear de frases curtas e longas, o estilo direto, expressivo, caricatural e irônico, enfim os usos modernos da linguagem e do discurso, credenciais que tornavam Lobato um renovador da língua literária e jornalística e o distanciava dos contemporâneos, apegados às fórmulas consagradas, à estrita observância da gramática e ao convencionalismo. Festejado como novo na abordagem, temática e forma, o fazendeiroescritor rapidamente cruzou os portais do então acanhado mundo intelectual paulistano.

$\mathrm{Na}$ produção ficcional, jornalística e nas cartas trocadas por Monteiro Lobato com amigos, especialmente Godofredo Rangel, pode-se discernir, desde muito cedo, um projeto de brasilidade que extravasava as fronteiras literárias, o que não se constituía propriamente em novidade - afinal, uma das marcas da intelectualidade brasileira é a obstinação em desvendar a "realidade nacional" e apontar caminhos para a nação; de tal sorte que o engajamento "se torna a condição ética do homem de letras". ${ }^{11}$

A especificidade de Lobato é dupla, pois não apenas seus escritos alcançaram enorme difusão - basta lembrar que seu primeiro livro, Urupês, teve nove edições em cinco anos - como o escritor foi capaz de enfeixar, sobretudo entre 1918 e 1925, várias instâncias de consagração simbólicas, que lhe valeram posição de destaque no campo intelectual e possibilitaram condições privilegiadas de intervenção no espaço público. 
Ainda que o seu projeto estético-político tenha indicado caminhos que foram percorridos pelos modernistas, é forçoso admitir que ele "não foi moderno como os modernistas o foram". ${ }^{12}$ Nada revela melhor tal distanciamento do que sua crítica à pintora Anita Malfatti (1917) que, longe de indicar incapacidade de entendimento da arte moderna, apontava para a recusa de uma proposta muito diversa do naturalismo e do nacionalismo propugnados por aquele que era um dos principais críticos de arte do cenário paulistano e que prescrevia a busca do verdadeiro Brasil no interior.

Para a vanguarda que realizou a Semana de 1922 e lutou para impor sua hegemonia no campo intelectual, uma das tarefas essenciais era combater o poderoso editor, escritor, crítico de arte, publicista e jornalista Monteiro Lobato, tarefa muito facilitada a partir de 1925, quando ele amargou a falência dos seus negócios editoriais e, pouco depois, deixou o país para assumir o cargo de adido comercial nos Estados Unidos (1927).

É preciso, portanto, não perder de vista as razões que fizeram dele um dos alvos privilegiados do bombardeio modernista, cuidado nem sempre tomado pelos historiadores da literatura, que simplesmente reproduziram, muitas vezes sem a necessária relativização e contextualização, os argumentos mobilizados pelos seus adversários, interessados em desqualificar não apenas Lobato mas todos os predecessores imediatos. A eficácia da ação pode ser avaliada pela consagração do termo "pré-modernismo" para designar o período imediatamente anterior à Semana de Arte Moderna. O prefixo não apenas carrega a noção de anterioridade e evoca a idéia de algo menor, inferior e incompleto, como apreende a produção que nomeia a partir de parâmetros que lhes são externos, admissão explícita da falta de essência e sentido próprios. ${ }^{13}$

A revisão crítica dessa construção tem dado margem a novas leituras acerca da produção e papel desempenhado pela intelectualidade do final do século XIX e início do XX. Se muitos dos escritores desse período permaneceram, até bem recentemente, esquecidos e soterrados na vala comum dos "pré-modernos", Lobato manteve-se em cena seja pela importância de sua produção infantil, por sua condição de símbolo da oposição à ditadura de Getúlio Vargas e pela luta apaixonada em prol do ferro e do petróleo, glórias que se não derivavam do mundo literário estrito senso, foram suficientemente poderosas para lhe assegurar lugar na galeria de personagens que compõem o patrimônio cultural compartilhado pelos brasileiros.

Esta introdução, ainda que sumária, é essencial para que se possa precisar os sentidos assumidos pela idéia de cidades mortas, outra das imagens duradouras que cunhou. A própria noção parece um contra-senso, pois caminha na direção oposta às representações, positivas ou negativas, elaboradas acerca do espaço urbano desde os primórdios da modernidade. Cabe então perguntar: qual o contexto de lançamento da obra, o que Monteiro Lobato entendia por cidade morta e que lugar a noção ocupou no projeto do autor.

\section{Cidades mortas: autor e livro no momento da edição}

O livro Cidades mortas foi lançado em fins de 1919, juntamente com Idéias de Jeca Tatu e a quinta edição de Urupês, que atingia a marca dos quinze mil exemplares impres- 
sos desde o lançamento, datado de julho do ano anterior. O próprio Monteiro Lobato era o editor responsável pelos empreendimentos, que ocorreram num momento particularmente favorável de sua carreira. Ele desfrutava do retumbante sucesso de Urupês, reunião de contos que marcou sua estréia literária e que inaugurou as edições da Revista do Brasil, mensário comprado em maio de 1918 e que então se constituía na principal publicação cultural do país, empreendimento que lhe conferia significativo poder e prestígio. ${ }^{14}$

As atividades de Monteiro Lobato no mercado editorial, iniciadas com a compra da revista, alteraram os padrões até então vigentes no comércio de livros. Consciente de que vendia uma mercadoria como qualquer outra - "faço livros e vendo-os... exatamente o negócio do que faz vassoura e vendê-as, do que faz chouriço e vende-os"15 -, investiu em publicidade e passou a anunciar sistematicamente os lançamentos na imprensa, prática ainda pouco disseminada. De saída atacou a distribuição, ponto mais fraco de toda a cadeia, e multiplicou os pontos de venda, enviando o que editava para papelarias, bazares, armarinhos, farmácias, lojas de ferragens e de fazendas. Preocupou-se em tornar o livro atraente, daí atentar para a qualidade da impressão e diagramação, multiplicar as ilustrações, colocar cor nas capas, ter em conta a divisão interna do texto, propor formatos inovadores, baixar custos e, sem deixar de acolher nomes consagrados, abrir as portas da editora para os que então despontavam no mundo das letras, aspecto igualmente inusitado, uma vez mesmo nomes reconhecidos enfrentavam dificuldades para publicar seus trabalhos.

Para produzir na quantidade e qualidade desejada o novo editor, já em 1919, entrou no ramo gráfico. Os resultados não tardaram: nesse ano a editora lançou quinze obras, num total de sessenta mil exemplares, cifras ainda modestas perto dos duzentos mil volumes das cinqüenta edições de 1921.

Monteiro Lobato envolveu-se, exatamente nessa época, em várias polêmicas, a exemplo da batalha em prol da língua brasileira, tema candente no final da década de 1910 e amplamente debatido nas páginas da sua revista. Defendeu a incorporação do léxico e das construções locais, independentemente do que rezasse a gramática cujas regras, ditadas por especialistas lusos, insistiam em negar foro de linguagem culta aos fenômenos observados no português da América. A questão assumia conotações políticas na medida em que, para muitos, a auto-afirmação da nação brasileira passava pela contestação da herança recebida de Portugal e sua suposta prerrogativa de impor regras no campo cultural, aí incluídas as normas cultas da língua. O coro dos que defendiam a existência de uma língua brasileira e dos que, mesmo admitindo a unidade, não abriam mão do direito à diversidade foi amplificado por Lobato, que também nesse aspecto pontificou na defesa do nacional.

Vale assinalar que seu capital simbólico não provinha apenas do campo estritamente cultural e literário. Logo após adquirir a Revista do Brasil e tornar-se editor, Lobato engajou-se de forma apaixonada na campanha em prol do saneamento dos sertões, causa que ocupou lugar de destaque nas páginas de seu periódico, franqueado para as denúncias de higienistas e médicos de renome. Os artigos que ele próprio escreveu a respeito do assunto no jornal $O$ Estado de S. Paulo foram enfeixados no livro Problema Vital, publicado pela sua editora, sob os auspícios da Liga Pró-Saneamento do Brasil e da Sociedade 
Eugênica de São Paulo, com grande repercussão. Seu engajamento na campanha colaborou para torná-lo ainda mais conhecido.

Ao colocar a pena a serviço dos que denunciavam o quadro desolador do interior do país, Lobato selava seu compromisso com a realidade nacional. Seus predicados de escritor colaboravam para dar cor e dramaticidade ao fato de dois terços dos brasileiros sofrerem de endemias curáveis pela moderna medicina e, para além disso, ajudavam a difundir um novo paradigma acerca dos problemas nacionais, não mais ancorado na questão racial. Se a inexpressividade do país fora até então tida como resultado da incapacidade de um povo mestiço que, de acordo com as teorias raciais em voga, portava nas veias um sangue corrompido, graças às perspectivas abertas pela higiene era possível renovar a confiança no futuro.

Coerente com essa nova leitura de país, Lobato não hesitou em pedir desculpas ao Jeca logo primeira edição de Urupês, alçando-o de algoz à vítima da incúria governamental. Exatamente em 1919, quando vieram a lume a quarta e a quinta edição do livro, Lobato tornou mais incisivo o texto escusatório e agregou dura crítica às elites locais.

Em síntese, cumpre ter presente que ao lançar em 1919 Idéias de Jeca Tatu e Cidades mortas Monteiro Lobato já adquirira projeção nacional e controlava importantes instâncias de consagração simbólica.

\section{Cidades mortas: trajetória do livro}

A exemplo de Urupês, as duas obras de 1919 reuniam textos diversos, a maioria deles já publicados em órgãos da imprensa. Numa interpretação muito difundida e, pelo menos em parte, ensejada pelas notas introdutórias das primeiras edições, ${ }^{16}$ toma-se como certo que Lobato, no afã de aproveitar a excelente acolhida da obra de estréia e sem dispor de tempo para escrever, em função das demandas da editora, decidiu ir

\footnotetext{
(...) ao fundo das gavetas e começa a retirar contos, crônicas e artigos que desde os tempos acadêmicos viera publicando em jornais e revistas de circulação restrita. Reúne tudo isso, o bom e o mau ao lado do ótimo e do péssimo, e o resultado são livros como Cidades mortas, Negrinha [1920], O macaco que se fez. homem [1923], Idéias de Jeca Tatu, O mundo da Lua [1923] e Onda Verde [1921]. Nos três primeiros apresenta quase todos os contos até então escritos. Nos últimos, artigos e pequenas crônicas, também coisas antigas (...) Reunião sem muito critério, algo apressada, a que não se pode negar intuitos comerciais. ${ }^{17}$
}

Essa avaliação genérica do que veio a público em forma de livro entre o final da década de 1910 e o início da seguinte, período crucial da atuação de Monteiro Lobato no mundo letrado, tem sido questionada. No caso específico de Idéias de Jeca Tatu, cumpre destacar o trabalho de Tadeu Chiarelli, que investigou o sentido de Idéias no instante do lançamento. Ao atentar para a disposição dos textos, títulos, divisões internas, conteúdo, temática e abordagem, o autor evidenciou que, longe de se tratar de uma justaposição descuidada, a obra sistematizava os princípios de uma estética nacionalista, antiacadêmica e naturalista, bem como suas possibilidades efetivas de concretização. Por intermédio do 
livro, Lobato tratou de formular, fundamentar e difundir um projeto cultural situado na contra-mão do ideário modernista. ${ }^{18}$

Outros livros ainda aguardam por investimento semelhante. Entretanto, um aspecto prévio e que dificulta sobremaneira o trabalho com a obra lobatiana prende-se ao que Marisa Lajolo caracterizou como “instabilidade textual vertiginosa". ${ }^{19}$ De fato, há textos que foram publicados sucessivas vezes, com graus variáveis de modificações no conteúdo e em momentos muito diversos da carreira do autor, o que por certo requer atenção, uma vez que os efeitos agregados à autoria variam consideravelmente em vista da posição ocupada pelo escritor no "pequeno mundo dos intelectuais". Ao lado disso, artigos e contos alocados originalmente em determinada obra foram transferidos para outras ou simplesmente desapareceram em edições subseqüentes, quando o próprio Lobato organizou suas Obras Completas - trinta e quatro volumes, dezessete para crianças e igual montante para adultos -, publicadas pela editora Brasiliense (1946), dois anos antes de sua morte.

Assim, uma primeira decisão a ser enfrentada diante de um livro de Monteiro Lobato diz respeito a que edição usar, o que está longe de ser simples ou destituído de conseqüências. Tadeu Chiarelli, por exemplo, pode justificar o uso das Idéias de 1919, volume bem distinto do fixado em 1946, por não se propor a refletir sobre a trajetória global de Lobato e tampouco investigar os diferentes sentidos assumidos pela obra no transcorrer do tempo.

Problema análogo coloca-se para Cidades mortas, cujo percurso foi longo e atribulado. As quatro primeiras edições - 1919, 1920, 1921 e 1923 - estiveram sob a responsabilidade do editor Monteiro Lobato e, apesar de relativamente próximas no tempo, guardam consideráveis diferenças entre si. Em 1935 a Companhia Editora Nacional, da qual Lobato já não era proprietário, organizou o volume Contos leves que, além de Cidades mortas, enfeixou material proveniente de outros livros. Nova edição desse volume, alterado sobretudo (ainda que não exclusivamente) no que diz respeito à distribuição interna do conteúdo, ocorreu em 1941. Dois anos depois, em comemoração do jubileu de Urupês, surgiu a chamada Edição Ônibus, reunião de grande parte da produção ficcional do escritor, aí incluídas as Cidades mortas. Por fim em 1946, já sob os auspícios da Brasiliense, a versão definitiva do livro tornou-se o segundo volume das Obras Completas, série Literatura Geral, destinada a adultos, ${ }^{20}$ havendo registro de 25 edições da mesma até 1986, segundo informa Milena Ribeiro Martins.

Essa pesquisadora comparou todas as edições citadas e precisou a natureza das alterações impostas ao conteúdo, que incluíram sucessivos acréscimos, retiradas e reintroduções; mudanças na seqüência e adoção de diferentes critérios para sua divisão interna, sem esquecer os prefácios do próprio Monteiro Lobato (1919, 1920, 1921, 1923 e 1935) e as notas introdutórias, biográficas e resenhas críticas, presentes a partir de 1943 e que se multiplicaram nas muitas edições das Obras Completas. ${ }^{21}$

Além das características relacionadas à própria materialidade assumida pelo livro no decorrer do tempo, há que se considerar que a produção posterior de Lobato, aliada aos rumos da sua carreira e à fortuna crítica do escritor, impuseram resignificações às Cidades mortas que, para serem apreendidas, demandam análise articulada de todos esses 
aspectos. Tendo em vista os objetivos e limites do presente texto, optou-se por confrontar a edição inicial (1919) e final (1946), sem desprezar, entretanto, os prefácios elaborados por Lobato até 1935. Tal escolha também se justifica pelo fato de as versões situarem-se em momentos privilegiados da trajetória do autor - a confiança e prestígio dos verdes anos; o peso de muito revés e a dose de monumentalização alcançada na velhice.

\section{Monteiro Lobato e o Vale do Paraíba}

O título, Cidades mortas, associado ao pequeno texto de abertura (ver nota 12), distingue-se pelo tom saudosista e autobiográfico, como se o leitor estivesse preste a adentrar num mundo pretérito, que subsistia apenas nas lembranças do escritor. Eram cidades mortas; coisas antigas; mocidade morta que faziam suspirar: quantas saudades! Tanta evocação poderia surpreender, especialmente quando se leva em conta que pouco mais de dois anos separavam a partida de Lobato do Vale do Paraíba (outubro de 1917) e a publicação de Cidades mortas (novembro de 1919). É evidente que a nota expressava o tempo afetivo da rememoração, pouco afeito a racionalizações impostas pela cronologia.

A partir da perspectiva biográfica, pode-se afirmar que os laços de Lobato com o Vale foram sendo refeitos à medida que ele ampliava seus horizontes e experiências. Nascido e criado na região, o jovem Lobato rumou para a capital em 1897, com o intuito de prosseguir os estudos. Fixou residência numa São Paulo em aceleradas transformações e que muito contrastava com a familiar Taubaté. Eram tempos marcados por vigoroso crescimento populacional, fruto da imigração; grande expansão da área urbana, que dobrou entre 1899 e 1909, e das remodelações do prefeito Antonio Prado, processos que contribuíam para alterar a paisagem da até então provinciana capital do Estado. ${ }^{22}$

Entre 1900 e 1904, freqüentou o curso de Direito e vivenciou intensamente a boemia propiciada pela condição de estudante. Declarou-se formado menos pelo Largo de São Francisco, sede da Faculdade, do que pelo Largo do Rosário, em cujas proximidades situava-se o Café Guarani, ponto de encontro para intermináveis discussões literárias com os amigos. O retorno do doutor Lobato a Taubaté foi marcado por aclamações e festas que, na sua avaliação, destinavam-se a agradar o avô, senhor de terras e visconde em plena República. Somente em 1907 o jovem advogado conseguiu ser nomeado, graças à influência do Visconde, Promotor Público na pequena cidade de Areias, cargo que ocupou até tornar-se fazendeiro (1911). Portanto, aos sete anos de ausência do estudante, seguiram-se quase catorze de permanência, cuja reconstituição apóia-se, em ampla medida, nas cartas enviadas a Godofredo Rangel. ${ }^{23}$

Se é licito supor que as relações afetivas com o Vale nunca foram cortadas, daí as saudades de um tempo distante no qual a leitura de mundo ainda se circunscrevia ao universo interiorano, a apreensão acerca do local de nascimento foi sendo reconstruída no confronto com centros econômicos mais dinâmicos do país - Rio de Janeiro, São Paulo e as áreas prósperas do interior paulista - e com as experiências derivadas das atividades de promotor, fazendeiro e homem de letras. Na sua longa correspondência, não seria difícil pinçar tanto exemplos positivos quanto negativos acerca do Vale, ainda que haja evidente predominância das observações críticas. 
Em mais de uma oportunidade Monteiro Lobato louvou a paz e o sossego que permitiam pensar e estudar, como se observa em cartas dos tempos de estudante (02/ 06/1904) e da promotoria (27/09/1910): "Ainda não ataquei os meus novos Nietzsches porque é coisa que requer silêncio e concentração, e este São Paulo (...) anda um horror de barulho. Felizmente as férias estão chegando, e naquele plácido remanso de Taubaté posso dar um mergulho de todo um mês no meu filósofo", ou ainda, "Ando ansioso por Areias - parece incrível! Mas aquele sossego me faz bem à alma e ao cérebro. Não há este dispersivo das grandes cidades". Já o tom ácido e de quase revolta perpassa as missivas do recém formado (31/12/1904) e as ponderações do promotor (02/12/1908): "Exílio, Rangel, pura verdade! Saltar da libérrima vida estudantina de São Paulo e cair neste convencionalismo de aldeia (...) Sinto-me rodeado de conspiradores; todos tramam o meu achatamento. Tudo quanto mais prezamos - o nosso individualismo etc é crime de lesa-aldeia"; e, depois, "Eu divido o mundo em duas partes: aonde se ouve apito de trem e aonde não se ouve apito de trem. Uma é o inferno, outra é o céu. (...). Para neutralizar esta Areias sem apito tomei uma assinatura do Weekly Times, de Londres, (...) e com os pés na grade da sacada injeto-me de inglês, de pensamento inglês, de política inglesa, enquanto pela rua passam os bípedes que vão mexer a panelinha da política local". ${ }^{24}$

As cartas dos anos passados no Vale atestam que foi nesse período que se efetivou a formação do Lobato escritor, que se "vingava" da pasmaceira local lendo, escrevendo e discutindo com o amigo Rangel, outro "exilado" numa comarca sem apito de Minas Gerais. E, de fato, muito do que publicaria posteriormente em livro foi concebido no tempo longo de Areias e da fazenda Buquira, o que talvez explique o recurso à expressão coisas antigas na abertura de Cidades mortas.

Contudo, tal afirmação foi tomada no sentido literal pelo seu principal biógrafo, Edgard Cavalheiro, que influenciou significativamente as interpretações sobre a produção lobatiana. Análise atenta do percurso dos textos que compõem o livro, levada a cabo por Milena Ribeiro Martins, revelou um quadro bem diverso. A pesquisadora distinguiu entre o momento da concepção e primeira escritura do conto, crônica ou artigo, que por vezes remontava ao início do século XX; as suas sucessivas publicações em jornais ou revistas, sempre com intervenções do autor que configuram uma re-escritura; e, por fim, a versão incluída na edição de $1919 .{ }^{25}$

Sob essa perspectiva, não se tratava mais de um punhado de coisas antigas dos tempos de estudante, de Areias ou da fazenda, mas de uma re-elaboração assinada em 1919 por um Lobato já famoso, e é sob essa perspectiva que devem ser analisados. Aliás, não se deve esquecer que já na segunda edição (1920), que incorporou apenas um texto (O romance do chupim) recém publicado na Revista do Brasil, a frase final da nota introdutória - “Oblivion, Itaoca... Quantas saudades!" - foi substituída por "Há também alguma coisa moderna". ${ }^{26}$ A mudança impôs brusca interrupção no fio da rememoração, substituído pela informação acerca do tempo da escritura (antigo e moderno), como se o autor desejasse relativizar a idéia anterior - um punhado de coisas antigas - pela noção mais flexível de maior ou menor proximidade temporal da produção, já que é natural que o escritor tivesse plena consciência do processo contínuo de re-elaboração a que submetia os textos. 


\section{Cidades mortas e o Vale do Paraíba}

A edição de 1919 compõe-se de vinte e quatro textos de gêneros diversos. O artigo de abertura, também intitulado Cidades mortas, sintetiza suas idéias acerca dos problemas do Vale e atua como espécie de preâmbulo explicativo ao conteúdo ficcional, em grande parte ambientado na região.

Logo no parágrafo inicial Monteiro Lobato afirma que "o progresso entre nós é nômade, e sujeito a paralisias súbitas. Radica-se mal (...) É um progresso cigano - vive acampando. Emigra, deixando atrás de si um rastilho de taperas". ${ }^{27}$ Tal itinerância é associada ao esgotamento da fertilidade da terra. Em vez de lutar contra "a avareza crescente do solo" e "criar fontes novas de riquezas, diversas das costumeiras", o homem forte emigra e o fraco "tomba em modorra para logo atolar na miséria". No Estado de São Paulo, a região do Vale do Paraíba seria o exemplo perfeito desse processo pois, nas palavras de Lobato, "ali tudo foi, nada é. Não se conjugam verbos no presente. Tudo é pretérito."

Estabelecidas as causas do processo, o escritor voltava-se para seus efeitos num conjunto de "cidades moribundas" que "arrasta um viver decrépito, gasto em chorar na mesquinhez atual as saudosas grandezas de outrora" (p. 8). Como signos da decadência, arrolavam-se ruas ermas, silenciosas e cortadas por raros carros de boi; armazéns fechados; restos de um antigo teatro; casarões apalaçados, com seus salões vazios, recheados de fendas e goteiras, atravessados pelo bafio da morte e habitados por uma prole estiolada, que não mais sabia nomear os augustos ascendentes pendurados nas paredes. A ligação com o mundo exterior ficava por conta do correio e suas duas malas postais, "murchas como figo seco" (p. 10).

Dos atributos externos, o escritor volta-se para os sociais. No topo da hierarquia das cidades mortas, alguns poucos ricos, aposentados que viviam de "apólices a render no Rio; e os sinecuristas apenduricalhados ao orçamento" (p. 9), o resto eram famílias decaídas, muitas moças casadoiras, já que os rapazes logo emigravam, velhos negros miseráveis e mestiços apáticos. Nessas cidades destituídas de vida e atividade, os pedreiros remendavam e escoravam paredes e muros em vez de construírem e os carapinas tornavam-se meros demolidores.

A desolação estende-se para os campos, "onde reina soberana a saúva e seus aliados o sapé e a samambaia." (p. 10). A passagem do Átila - café nada deixou atrás de si, exceto algumas marcas de um passado próspero e um punhado de "caboclos amarelos, opilados (...) verdadeiros vegetais de carne que não florescem nem frutificam” (p. 11), descrição que imediatamente remetia à figura do Jeca Tatu. O progresso cigano abandonou a região e rumou para as terras férteis localizadas à oeste.

Em poucas páginas e valendo-se de metáforas e imagens fortes, Monteiro Lobato descreveu a situação reinante no Vale do Paraíba. Contrariamente ao que se anunciava na nota introdutória, não se tratava de revisitar um passado distante, mas de fornecer um retrato contemporâneo da triste herança do café. Se a abertura de novas zonas pioneiras era tomada como sinônimo de avanço econômico pelas elites brasileiras, o escritor destoava ao insistir nos efeitos de uma prosperidade errante, que tanto criava cidades como 
Ribeirão Preto, então sinônimo da riqueza do Estado de São Paulo, quanto as sonolentas cidades do Vale. Ao fechar o texto com uma referência ao "tempo feliz em que Ribeirão Preto era lá [no Vale]...", Lobato convidava o leitor a concluir que nenhuma cidade era realmente uma Ribeirão Preto, apenas desfrutava temporariamente de tal condição. Raciocínio análogo poderia ser aplicado à decadência do Vale do Paraíba que, longe de ser específica e limitada à região, pairava como uma terrível ameaça sobre áreas ainda férteis e prósperas que estavam ameaçadas de engrossar o rol das cidades mortas.

O texto inicial da obra pode ser visto como um manifesto que, ao mesmo tempo, critica o modelo econômico predominante no país, ancorado na exploração predatória das riquezas naturais, e estabelece a grande linha de força do livro. O diagnóstico não provinha de um curioso, mas de alguém que conhecia de perto a realidade examinada e contabilizava larga e diversificada vivência na região.

\section{Cidades mortas: metáfora para o Brasil?}

É de se notar que, exceção feita ao texto comentado, não há menção específica ao Vale do Paraíba no restante do livro: ao se referir às cidades mortas Lobato sempre recorre a nomes imaginários, Oblivion (que remete a oblívio, ou seja, esquecimento) e Itaoca (do tupi, casa de pedra, lugar retirado e esquisito). Nessa perspectiva, pode-se atribuir sentido simbólico ao Vale e supor que Lobato estava menos interessado na área em si do que em fazer dela metáfora para o país.

Este aspecto, que nos parece essencial, foi esmaecido nas interpretações sobre Cidades mortas, que insistem em circunscrever os problemas abordados a um dado espaço geográfico. A própria coesão do livro pode ser reinterpretada a partir dessa abordagem. Entre as críticas freqüentes estão as que insistem na falta de articulação do conteúdo, o que de fato é pertinente no que se refere à presença de alguns textos (Tragédia de salão, Duas dançarinas, Em casa de Fídias e $A$ poesia e o poeta) que não guardam relação com a temática anunciada. Talvez por haver se dado conta do fato, o próprio Lobato os tenha excluído logo nas edições seguintes. ${ }^{28}$

Ao lado deste aspecto, porém, aponta-se como índice de incoerência a presença de narrativas que poderiam se desenrolar em qualquer cidade, assim como a referência a uma Itaoca litorânea ou à cidade de São Paulo. Ora, se tais escolhas têm sido citadas como índices da pressa de Lobato em reunir fundos de gaveta e da falta de unidade do conjunto, pode-se argumentar em direção diversa e entendê-las como indicação de que ele não se pautou, em momento algum, por critérios geográficos, ainda que haja forte intertextualidade entre o artigo de abertura e grande parte do material subseqüente.

A nota da terceira edição (1921), na qual o autor fez questão de afirmar o caráter não territorial de Itaoca, parece abonar tal conclusão:

Este livro reflete a alma de Itaoca, e um bocado a de São Paulo.

- Mas Itaoca onde é?

- Em toda parte. Em toda parte onde uma cidadezinha vegeta de cócoras ante um coronel da guarda, um vigário e uma queda de truco que não tem fim. 
Coitadinha de Itaoca! Já foi, não é. Vive do passado, a rememorá-lo, saudosa, sem esperanças de futuro. Se a estrada de ferro viesse... Se viesse o telégrafo... Se... Se... ${ }^{29}$

Observe-se que o autor abandonou as explicações de cunho memorialísticos $\left(1^{\mathrm{a}}\right.$ edição), bem como a referência ao momento da escritura do texto, incorporada na $2^{\text {a }}$ edição e que serviu de guia para a organização do conteúdo do livro em duas outras oportunidades, ${ }^{30}$ em prol da explicitação do significado simbólico de Itaoca, o que foi feito por intermédio de uma pergunta retórica - "Mas Itaoca onde é?" Na resposta, o escritor insiste que seu objetivo é refletir a alma de Itaoca, o que equivale a dizer que os aspectos ligados à materialidade adquirem importância secundária diante da tarefa maior de buscar sua essência mais íntima (alma).

Contudo, Lobato introduz nova ambigüidade ao afirmar que Cidades mortas também refletia "um bocado a [alma] de São Paulo". Mas que São Paulo: a capital, o Estado ou ambos? Ainda que seja possível argumentar em diferentes sentidos, deve-se destacar o fato de o autor e editor haver excluído da terceira edição justamente o único conto cujo enredo se desenrolava, explicitamente, num lugar concreto e localizável, a cidade de São Paulo (Imposto único), atitude consoante com a nova nota introdutória, que insistia no caráter metafórico da obra, aspecto ausente das notas prefaciais anteriores.

Cidades mortas fornece um quadro bastante pessimista acerca das elites do país e dos valores que cultivavam, como se verá a seguir. Convém alertar que, em lugar de comentar isoladamente cada um dos textos, o que poderia implicar em muitas repetições, ou tentar agrupá-los em tipologias sugeridas por possíveis recortes temáticos, método útil mas que não raro implica em reducionismos a fim de sujeitar o texto literário a um rol pré-determinado de variáveis, optou-se por destacar os principais alvos das críticas de Monteiro Lobato, apreensíveis a partir do conjunto da obra, sem perder de vista o nosso objetivo, qual seja, evidenciar que os dilemas enfrentados pelas cidades mortas não se constituíam em apanágio exclusivo das mesmas, ainda que pudessem se apresentar de forma potencializada nas áreas decadentes.

Aliás, são justamente os indícios de que o progresso apenas passou por Itaoca e Oblivion que fornecem matéria prima para a construção ficcional. O escritor, em várias oportunidades, insiste nos hábitos rotineiros dos habitantes; ${ }^{31}$ na indistinção dos dias da semana, fato que teria inspirado um engenhoso farmacêutico do interior a inventar a folhinha, única forma de saber se era segunda ou quarta; ${ }^{32}$ no sufocante silêncio, quebrado por perturbadores eventuais, entre eles o carrinho da Câmara Municipal, o veículo mais importante da cidade, enferrujado pelo raro uso e que infernizava os moradores quando saia em busca de algum terrível formigueiro. ${ }^{33}$ Tanta mesmice era aplacada com a "ambrósia dos lugares pobres", o mexerico, cujo centro era a farmácia. ${ }^{34} \mathrm{O}$ ramerrão cotidiano era quebrado pelo carnaval, pelo calendário de festas religiosas ou pela chegada de um circo. ${ }^{35}$

Esta descrição de personagens e situações típicas de cidades mortas convive ao lado de outras, não remissíveis a espaços determinados. É o caso das várias considerações acerca do poder público, sua burocracia e justiça; do abandono material e espiritual da população; da superficialidade das relações sociais; do despreparo das elites econômicas e das práticas e valores abraçados pela intelectualidade brasileira, temáticas recor- 
rentes nos textos que compõem as Cidades mortas e que não podem ser circunscritas às mesmas.

Monteiro Lobato critica duramente o "servidor da pátria", caracterizado como "inutilidade comprovada" sem os quais "os negócios do estado marchariam na mesma, senão melhor" (pp. 29-30). Mas é no conto O luzeiro agrícola que o autor atacou frontalmente a questão, por meio da ironia e do sarcasmo, patentes já na primeira frase, que apresenta o anti-herói, Sizenando Capistrano, como inspetor agrícola do centésimo distrito - e atente-se para o número: havia, portanto, pelo menos uma centena de inspetores espalhados pelo país afora. Lobato descreve as peripécias do poeta Sizenando antes de se tornar funcionário - e não se pode esquecer que um traço distintivo dos homens de letras, sobretudo no século XIX e início do seguinte, residia no fato da quase totalidade exercer cargos públicos. O personagem obteve o emprego por meio de relações clientelísticas; foi recomendado e apresentado a uma figura importante e suplicou, com comovente humildade: “- Então menino, o que quer? - Um empreguinho qualquer que Vossa Onipotência haja por bem conceder-me” (p. 166). O fato de o candidato não possuir nenhum dos conhecimentos requeridos para o bom exercício da função pouco importava, como se vê num pequeno trecho da conversa entre o poeta e seu possível protetor:

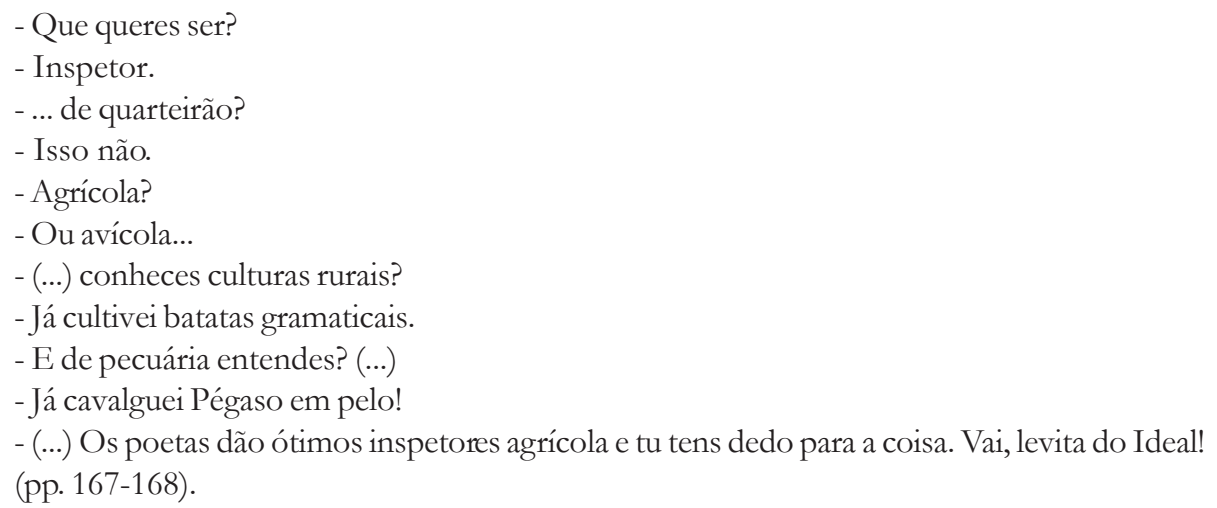

Animado com a nova ocupação, mas não sem antes gozar três meses de licença, o novo funcionário apresentou-se ao Ministro da Agricultura, que lhe ordena a confecção de um relatório sobre qualquer coisa. Passados dois anos, voltou Sizenando à presença do Ministro para entregar longuíssimo texto. Foi então informado que todo o material deveria ser enviado à Casa da Moeda para incineração. Diante da surpresa, segue-se a explicação:

- Então? Que queria você que eu fizesse de 5000 exemplares (...)? Que o pusesse à venda? Ninguém o compraria. Que o distribuísse grátis? Ninguém o aceitaria. Se é assim, se sempre foi assim, se sempre será assim com todas as publicações deste ministério, o mais prático é passar a edição diretamente da tipografia ao forno (...). Retire o que quiser e forno com o resto. - E depois, que devo fazer, indagou Sizenando (...)

- Escreva outro relatório, respondeu sem vacilar o ministro.

- Para ser queimado novamente? Atreveu-se a murmurar o poeta-inspetor. 
- Está claro, homem! Para que diabo despendeu o governo tanto dinheiro na montagem do forno? Está claro que para incinerar as notas velhas e os relatórios novos. Deste modo se conservam em atividade perpétua o pessoal da Imprensa, o do Forno e o dos Ministérios. Veja você como é sabia a nossa organização administrativa! (p. 170-171).

O descompromisso com a coisa pública, expresso na definição do Estado como "um boi gordo" ao qual se apegam, como carrapatos, muitos Capistranos, é recorrente em vários textos de cidades mortas. $\mathrm{O}$ resultado se fazia sentir na enorme distância entre o governo e o caboclo, um insulado "que não forma sociedade" e cujo contato com as autoridades dava-se, segundo Lobato, por intermédio do "inspetor de quarteirão, soldado do destacamento, juiz de paz no dia do casório” (p. 31). Talvez para tornar patente que a situação não era exclusividade das áreas rurais decadentes, Lobato descreve, no conto Imposto único, que deixou de figurar em Cidades mortas a partir da terceira edição, a atuação de fiscais da capital do Estado, que perseguem e extorquem implacavelmente a família de um garoto que resolvera engraxar sapatos para ajudar nas despesas da casa. A mensagem é explicita: o Estado está ausente e seus funcionários, quando atuam, o fazem segundo interesses espúrios.

A justiça, por sua vez, recebeu ácidas considerações do ex-promotor, por motivos diversos. Reconhecia que os pobres a ela "nunca recorrem... - têm-lhe medo, sabem como ela é iníqua [para com eles]” (p. 32). Lobato também não perdeu a oportunidade de criticar a concepção clássica do direito, que enfatizava o delito, em prol da escola positiva, mais interessada no criminoso e ancorada no pretenso cientificismo dos laudos médicos. Daí condenar os bacharéis que tinham "as cabeças abarrotadas de leis, regulamentos, decretos e fatos jurídicos, a modo de só tomarem conhecimento das relações entre o fato e a lei escrita, nunca entre o fato e a lei natural" (p. 38). Além disso, engrossou o rol daqueles que desde o século XIX questionavam a instituição do júri popular, ridicularizada num texto (Júri na roça) que narrava a incompreensão dos jurados diante dos intrincados procedimentos legais. ${ }^{36}$

Não era diverso o quadro de abandono quando se tratava de questões religiosas. Do catolicismo a população mais simples só absorveria os aspectos exteriores, não o sentido: guardavam-se os dias santos, organizavam-se procissões, mas contato efetivo com o padre só ocorria no batismo e casamento. ${ }^{37}$ A situação foi tema do conto Cabelos compridos, no qual a personagem Das Dores resolve colocar em prática o conselho de um famoso missionário, que recomendou aos fiéis meditar acerca das palavras contidas nas orações cotidianas, sem o que o ato não teria valor. Os resultados da empreitada, explorados com humor por Lobato, foram desastrosos e a moça adormeceu sem concluir nem mesmo um Pai Nosso. Conclusão: "Das Dores continuou a rezar pelo sistema antigo, mais rápido, mais correntio" (p. 76).

A superficialidade e exterioridade, já apontadas para a devoção religiosa, também contaminavam as relações sociais. Em vários contos o escritor critica o apego à regras de polidez excessivas e artificiais, ou a dissimulação das intenções, o que acaba por resultar em situações tragicômicas, caso dos contos Fígado indiscreto, De como quebrei a cabeça à mulher do Melo, Tragédia de salão e As seis decepcões, ou denuncia a hipocrisia dos comportamentos, como em A Cruz de Ouro, nome do bordel freqüentado pelos guardiões da 
moralidade. Diante da educação e conduta postiças, as crenças populares surgiam como mais autênticas e vigorosas, como no conto Pedro Pichorra, sobre o Saci-Pererê.

A elite econômica não mereceu melhor consideração. Segundo Lobato, caso os fazendeiros mais ilustres do país tivessem que escolher entre derrubar uma floresta ou pensar por meia hora, não bastariam cinco minutos para se ouvir o som dos machados. ${ }^{38}$

As críticas mais ácidas, porém, dirigiam-se à intelectualidade, seus hábitos, valores e aspirações. $\mathrm{O}$ homem de letras, símbolo da inteligência nacional, era o alvo privilegiado dos ataques e não por acaso vários de seus anti-heróis eram escritores e, sobretudo, escritores funcionários. Retoricamente perguntava: "Quem não é literato em nossa terra? Fažer literatura é a forma natural da calaçaria indígena" (p. 146, grifo no original).

A imitação de modelos provenientes do exterior, aliada à insistente recusa em tomar o país por objeto, tema constante da produção lobatiana, surge com força em vários dos textos de Cidades mortas. Não parece mera coincidência que, após o artigo de abertura, Lobato tenha decidido introduzir o leitor ao material ficcional pela temática literária. Em poucas páginas ele descreve a triste situação de Oblivion, cidade na qual os poucos que liam dispunham de apenas três livros: La maré d'Auteil, de Paul de Kock, "ad usum dos conhecedores do francês"; alguns poucos volumes do Rocambole, de Ponson de Terrail, "para enlevo das imaginações femininas" e Ilha maldita, de Bernardo de Guimarães, "para deleite dos paladares nacionalistas". E "essa trindade impressa bastava à educação literária da cidade" (p. 14). Não é preciso muito esforço para perceber que a crítica, ainda que personalizada na pobre Oblivion, efetivamente dirigia-se ao mundo letrado brasileiro, pautado no nacionalismo basbaque ("onde todo mundo vê carrapatos, pernilongos, espinheiros, Bernardo aponta doçuras, insetos maviosos, flores” (p. 16)), no romantismo e no apego à moda de Paris. ${ }^{39}$

O escritor não perdia a oportunidade de ridicularizar os letrados que se portavam como estrangeiros em sua própria terra. Com a visão turvada pelo desejo de ser o que não eram, subtraiam à literatura sua capacidade de compreender e produzir propostas de ação, transformando-a num mero conjunto de fórmulas inócuas e vazias, úteis para impressionar moças e senhoras, tal a mensagem que Lobato parece querer infundir ao leitor. Exemplo nesse sentido é fornecido pelo conto Noite de São João, no qual o escritor local, Júlio da Silva, que assinava Julius d'Alcatrava, marcava a tradicional quadrilha num curioso idioma misto - "En avant tour; Grande chêne; Tour, a pas de porca; Jújú d'enfant; Grande confusion! Tour!” (pp. 50-51) -, com o nobre fim de impressionar a bela Candoca.

Não apenas o literato provinciano recebia as estocadas de Lobato. No conto $O$ resto de onça, ele ridiculariza a produção da Academia Brasileira de Letras e seus imortais. A título de comentar a obra de Alberto Pessegueiro (a partir da $2^{a}$ edição denominado Alberto de Oliveira), Lobato expõe uma teoria do conto, numa tentativa pedagógica que visava fornecer elementos para que o leitor pudesse distinguir entre a boa e má escritura, mas não sem antes disparar contra os que "têm uma alma postiça, importada da França (...) [e] os estados por que passam tais almas, postos em letra de forma, são coisa pulha e maçadora, até não mais poder” (p. 82).

O problema reaparece sob circunstâncias e roupagens diversas em outros textos de Cidades mortas, como na mania das conferências, quando "sábios" se dispõem a expli- 
car teorias complicadíssimas a um público incapaz de compreendê-lo (tema do conto Gens ennuyeux); no drama de consciência do funcionário-literato e plagiador Ernesto, "né de Oliveira, mas d'Olivaes por contingências estéticas” (p. 143), ${ }^{40}$ que, a exemplo do personagem Capistrano, obteve emprego público, sem deixar, porém, de colaborar com o periódico local; ou ainda no esforço encetado pelo reverendo de Gramática viva, "homem de luzes notórias, autor de vários acrósticos em latim” (p. 54), para receber condignamente um ilustre visitante estrangeiro, esforço que ia desde a caça ao breviário, há muito esquecido, a limpeza da casa, a escolha da toalha da mesa, roupa de cama e forma de tratamento até a renúncia mais dolorosa: o abandono do pito.

O distanciamento da elite pensante em relação ao país, fruto da importação servil de modelos estrangeiros, era constantemente ridicularizado pela pena do escritor, que tampouco perdoou o nacionalismo ingênuo, que cantava as belezas e riquezas do país. Os dois aspectos foram magistralmente explorados no conto $O$ espião alemão, que fecha a primeira edição de Cidades mortas.

A publicação do livro ocorreu em 1919, portanto pouco depois do término da $1^{\text {a }}$ Guerra Mundial, conflito no qual a participação do Brasil fora das mais modestas. O texto trata da participação de Itaoca na guerra, coordenada pela liderança política local: o coronel, o vigário, sintomaticamente denominado Acácio da Silva, homem que "sabe tudo, desde latim até astronomia", o juiz, o secretário da Câmara, um major veterano de antigas batalhas, o literato Leão Lobo, "mulatinho disfarçado", além de outros que "leram o Rocambole a fio e assinam as folhas governistas" (p. 197), caracterização que pode ser lida como síntese do poder político-cultural não apenas de Itaoca, mas de toda a nação.

Ainda que seja tentador, pela graça e vivacidade do texto, não reproduziremos as discussões acaloradas propiciadas pela guerra, bastando assinalar que as cabeças pensantes oficiaram, no melhor estilo beletrista, ao Presidente da República e criaram seu comité de Salvação Pública. Numa clara alusão à Liga de Defesa Nacional e à patriótica campanha do poeta Olavo Bilac em prol do serviço militar obrigatório, Lobato descreve os esforços de Itaoca para apurar seu sistema de defesa. Transformada em verdadeira praça de combate, a cidade treinou vinte rapazes no tiro de guerra, ainda que o armamento prometido pelo governo federal nunca tenha sido enviado e os voluntários se revezassem no uso de uma única espingarda.

Tudo corria bem até que a prisão de um estrangeiro, logo identificado como um perigoso espião alemão. E por mais que o suspeito afirmasse que era inglês - e aqui Lobato explora a situação por longos parágrafos para ridicularizar o saber do literato, do padre Acácio e dos demais luminares do lugar - ninguém foi capaz de entendê-lo. Diante da grave ameaça, valente destacamento, colocando em risco a própria vida pelo bem da pátria, escoltou o espião ao Rio de Janeiro.

Enquanto os heróis iniciavam sua jornada, a colônia alemã local, ou seja, o velho farmacêutico Muller, há sessenta anos residente no local, e sua criada, nascida em Blumenau, eram alvos da fúria popular, incitada pela elite local. Na Praça 7 de Setembro, que lembrava a data sagrada da independência, os oradores insistiam que Itaoca estava sobre um vulcão e recorriam ao exemplo da Bélgica para asseverar a necessidade urgente de um desagravo. Pode-se supor que o leitor da época imediatamente relacionasse a 
situação descrita com os muitos alertas sobre que a colônia alemã nos Estados do sul, que ameaçava a unidade nacional, tema igualmente caro a Bilac e à Liga de Defesa Nacional.

O risível está menos na mobilização de Itaoca em si, mas no vínculo entre tal agitação e o frenesi que tomou conta do país durante a guerra. Lobato satiriza a mobilização retórica e inútil, que julgava condizente com uma elite cujas atenções voltavam-se para o exterior. Porém, tal como o mundo não tinha conhecimento do que ocorria em Itaoca, o mesmo valia para o Brasil, país sem qualquer expressão no conserto das nações, para recorrer a um termo da época. E o escritor prossegue de forma implacável. Mesmo depois do engano ter sido desfeito, os expedicionários foram recebidos, graças aos esforços de um grande patriota, o literato Leão Lobo, que não satisfeito em rebatizar as ruas com o nome dos corajosos soldados, andava "amadurecendo a idéia de pedir a Clemenceau uma fita da Legião de Honra para a lapela da mui leal e invita Itaoca. E vão ver que ainda Clemenceau acaba fazendo-lhe a vontade, e dando a ele, de lambujem, o Mérite Agricole. Merecidíssimo, aliás, pois não, pois não” (p. 210).

\section{Cidades mortas em 1946}

$\mathrm{Na}$ edição definitiva de suas Obras Completas, Monteiro Lobato deslocou para Cidades mortas textos originalmente concebidos e/ou publicados entre 1900 e final da década de 1930, além de metade do conteúdo do livro $O$ macaco que se fez homem, editado uma única vez em 1923. Optou por alocá-los no final do volume, atitude que aponta, na própria materialidade da obra, a tardia incorporação. Pode-se argumentar que talvez o movesse o desejo de preservar o conjunto original e que se não se tratou, conforme normalmente se afirma, de uma simples justaposição. A leitura atenta permite estabelecer nexos temáticos entre as narrativas anexadas e aquelas presentes na edição inaugural de Cidades mortas.

Nessa perspectiva, pode-se argumentar que não é destituída de sentido a idéia de que Café, café e Tragédia dum capão de pintos integram-se ao universo de Cidades mortas por relatar aspectos da vida rural brasileira, ordenada em torno do café; Toque outra guarda relação com textos que insistem no convencionalismo e superficialidade dos salões educados; Romance de chupim e Um homem honesto poderiam ser relacionados a Porque Lopes se casou, uma vez que se aproximam pela temática do casamento; Um homem de consciência dialoga com a questão da apropriação privada do público, tema recorrente no livro; $N u$ vem de gafanhotos e $O$ rapto também tratam da exploração, agora levada a efeito não pelo Estado e sua burocracia, mas por pretensos amigos e familiares; Anta que berra e $O$ resto de onça podem ser aproximados na medida em que problematizam o gênero conto. Talvez Era no paraíso seja a narrativa mais apartada do núcleo original, já que trata de uma nova leitura da criação divina, que permite a Lobato construir uma visão bastante cética da humanidade como um todo. Em síntese, a estrutura interna de Cidades mortas guardou coerência, apesar de seu atribulado percurso editorial e da grande distância entre a edição original e a definitiva. 


\section{Conclusão}

As análises apresentadas, ainda que sem pretensão de dar conta de todas as temáticas presentes em Cidades mortas, permitem afirmar que o livro tinha escopo bem mais amplo do que caracterizar a decadência do Vale do Paraíba. De fato, a região forneceu o contexto a partir do qual Lobato sistematizou, com humor e ironia, suas críticas às elites econômicas, políticas e intelectuais que gerenciavam o país. Tais intenções parecem claras quando se atenta para a estrutura interna da obra, seu conteúdo e as diferentes notas prefaciais do autor, que fornecem indícios, cada vez mais explícitos, acerca das intenções que o moviam. Entretanto, a fortuna crítica da obra mostra que os intérpretes têm sistematicamente restringido o sentido da obra, o que pode ser entendido como uma estratégia, consciente ou não, de empalidecer o próprio projeto lobatiano imaginado para o país, uma vez que diminuir o alcance crítico e político das cidades mortas também é uma forma de silenciar acerca de uma possibilidade de futuro imaginada para a nação brasileira.

O texto definitivo de Cidades mortas foi publicado nas Obras Completas. Grande distância separava o Lobato de 1919 e o de 1946, observação igualmente válida para o país e seus dilemas. Porém, o cerne das críticas do escritor manteve-se inalterado, ainda que o diagnóstico tenha se tornado mais complexo e as soluções sugeridas outras. Às causas do progresso efêmero, antes referenciado na agricultura, juntava-se agora a incapacidade de explorar as riquezas naturais, o ferro (siderurgia) e o petróleo (fontes de energia), batalhas que abraçou nas últimas décadas de sua vida. O descaso governamental, o uso da máquina pública, os interesses espúrios, o abandono da população e a crítica à intelectualidade continuaram presentes nas suas obras, ainda que emolduradas num quadro diverso, próximo das posturas antiimperialistas e chegando mesmo a resvalar no comunismo, ideologia da qual se aproximou nos seus últimos anos, sem nunca ter se filiado ao partido. A criação do personagem Zé Brasil, vítima não mais do sangue mestiço ou da falta de cuidados médicos, mas da estrutura fundiária injusta, apontam para inflexões significativas na sua apreensão do país. ${ }^{41}$ Não parece demais afirmar, no entanto, que ele se manteve fiel ao seu projeto nacionalista e que até o final da vida abraçou os ideais que o moviam em 1919, segundo os quais as elites brasileiras continuavam apartadas do país e de seu povo, os recursos mal aproveitados, o progresso nômade e instável, a nação morta e sem futuro.

\section{Notas}

\footnotetext{
${ }^{1}$ Agradeço a leitura e as sugestões de Flávia Arlanch Martins de Oliveira, Marisa Lajolo e Milton Carlos Costa. Versão resumida desse texto, a ser publicado em livro na França, foi apresentada no seminário La ville au Brésil: XVII ${ }^{\mathrm{ème}}$ - XX ${ }^{\mathrm{ème}}$ siècles, naissances et renaissances, realizado em La Rochelle (2005).

${ }^{2}$ CASTRO, Hebe Maria de; SCHNOOR, Eduardo (org.). Resgate, uma janela para o oitocentos. Rio de Janeiro: Topbooks, 1995. As informações que se seguem foram retiradas desta obra.

${ }^{3}$ Idem, p. 227.

${ }^{4}$ ALMEIDA, João Gabriel Roda de. O ingrato promotor de Oblivion: A memória da cidade de Areias acerca de Monteiro Lobato. Mestrado (História). Rio de Janeiro: UERJ, Instituto de Filosofia e Ciências Humanas, 2005.
} 
${ }^{5}$ Uma das principais biografias do autor, que caminha na direção apontada, foi escrita por CAVALHEIRO, Edgard. Monteiro Lobato. Vida e obra. $3^{\mathrm{a}}$ ed. São Paulo: Brasiliense, 1962, 2v.

${ }^{6}$ KOSHIAMA, Alice M. Monteiro Lobato intelectual, empresário, editor. São Paulo: T. A. Queiroz, 1982 e PASSIANI, Ênio. Nas trilhas do Jeca: Monteiro Lobato e a formação do campo literário brasileiro. Bauru, SP: EDUSC, 2003. ${ }^{7}$ LAJOLO, Marisa; ZILBERMAN, Regina. Literatura infantil brasileira: história e histórias. São Paulo: Ática, 1985.

${ }^{8}$ PETEADO, J. Whitaker. Os filhos de Lobato: o imaginário infantil na ideologia do adulto. Rio de Janeiro: Qualitymark: Dunya, 1997.

${ }^{9}$ Monteiro Lobato nasceu em 1882, na cidade de Taubaté, região do Vale do Paraíba paulista, onde cursou as primeiras letras. Ainda adolescente perdeu os pais, cabendo ao avô materno, o Visconde de Tremembé, a guarda dos netos. Apesar da inclinação para a pintura, atendeu às imposições familiares e ingressou na Faculdade de Direito (1900). Exerceu o cargo de Promotor Público em Areias (1907-1911), que abandonou ao receber, por herança, as terras do avô (1911). Em 1917, vendeu a fazenda e mudou-se para São Paulo, passando a dedicar-se à literatura, jornalismo e atividades editoriais.

${ }^{10}$ A respeito ver: CAMPOS, André Luiz Vieira de. A República do Picapan Amarelo. Uma leitura de Monteiro Lobato. São Paulo: Martins Fontes, 1986, pp. 3-44; LAJOLO, Marisa. Jeca Tatu em três tempos. In: SCHWARZ, Roberto (org.). Os pobres na literatura brasileira. São Paulo: Brasiliense, 1983, pp. 101-105; NAXARA, Márcia Regina C. Estrangeiros em sua própria terra. Representações do brasileiro (1870/1920). São Paulo: Annablume: FAPESP, 1998, pp. 23-33.

${ }^{11}$ SEVCENKO, Nicolau. Literatura como missão. Tensões sociais e criação cultural na Primeira República. $3^{\mathrm{a}}$ ed. São Paulo: Brasiliense, 1989, pp. 78-79.

${ }^{12}$ CHIARELLI, Tadeu. Um Jeca nos vernissages. Monteiro Lobato e o desejo de uma arte nacional no Brasil. São Paulo: EDUSP, 1995, p. 227. Livro que analisa o papel de Lobato como crítico de arte, reavalia o episódio Anita Malfatti e as relações entre o escritor e os modernistas.

${ }^{13}$ Para uma análise crítica da utilização do prefixo consultar: FUNDAÇÃO CASA DE RUI BARBOSA. Sobre o pré-modernismo. Rio de Janeiro: Casa de Rui Barbosa, 1986; MICELI, Sérgio. Poder, sexo e letras na República Velha. São Paulo: Perspectiva, 1977.

${ }^{14} \mathrm{Na}$ sua primeira fase, a revista circulou mensal e ininterruptamente por nove anos (1916-1925), tendo sido publicados um total de 113 exemplares. Acerca da revista em si e do lugar estratégico que ocupou nos empreendimentos e na construção da imagem de Monteiro Lobato ver: DE LUCA, Tania Regina. A Revista do Brasil:um diagnóstico para a (N)ação. São Paulo: UNESP, 1999;

${ }^{15}$ LOBATO, José Bento Monteiro. A barca de Gleyre. 11a ed. São Paulo: Brasiliense, 1964, v. 2, p. 202. Carta a Godofredo Rangel, datada de 17/01/1920.

${ }^{16}$ Na primeira edição de Cidades mortas lê-se: "Entra neste livro um punhado de coisas antigas, impressões d'uma mocidade morta que vegetou no ambiente marasmático das cidades mortas. Oblivion, Itaóca... Quantas saudades!... ", enquanto a abertura de Idéias de Jeca Tatu inicia-se com a seguinte frase: "Uma idéia central unifica a maioria destes artigos, dados à estampa em O Estado de S. Paulo, na Revista do Brasile em outros periódicos." ${ }^{17}$ CAVALHEIRO, Edgard. Op. cit, v.1, pp. 118 e 237.

${ }^{18}$ CHIARELLI, Tadeu. Op. cit., pp. 218-252.

${ }^{19}$ LAJOLO, Marisa. Monteiro Lobato: um brasileiro sob medida. São Paulo: Moderna, 2002, p. 66.

${ }^{20}$ Monteiro Lobato viu-se obrigado a vender sua parte na Companhia Editora Nacional no início dos anos 1930, em conseqüência do revés financeiro sofrido com a quebra da bolsa de Nova York, mas permaneceu ligado à casa até receber oferta da então jovem Editora Brasiliense, que desejava editar a totalidade de sua obra.

${ }^{21}$ MARTINS, Milena Ribeiro. Lobato edita Lobato: história das edições dos contos lobatianos. Tese (doutorado em Letras). Campinas: UNICAMP, Instituto de Estudos da Linguagem, 2003, pp. 211-285, retraça o percurso da obra e transcreve os prefácios e paratextos das diferentes edições. Os quadros comparativos elaborados pela autora permitem visualizar, com clareza, as muitas mudanças introduzidas na obra ao longo do tempo.

${ }^{22}$ LOVE, Joseph. A locomotiva. São Paulo na federação brasileira 1889-1937. Rio de Janeiro: Paz e Terra, 1982, pp. $120-121$.

${ }^{23}$ A correspondência com Rangel (1903-1948) permite divisar, para além do percurso de Lobato - vida estudantil, processo de criação, concepções e atuação no campo das letras e fora dele -, hábitos e práticas do campo literário, da leitura e da escrita, ultrapassando o mero testemunho de caráter particular e pessoal. Sobre as 
características da correspondência, as intervenções de Lobato no seu conteúdo e os sentidos de sua divulgação na década de 1940 consultar: DE LUCA, Tania Regina. Monteiro Lobato: estratégias de poder e auto-representação n'A Barca de Gleyre. IN: GOMES, Angela de Castro (org). Escritas de si, escritas da bistória. Rio de Janeiro: FGV, 2004, pp. 139-161.

${ }^{24}$ LOBATO, José Bento Monteiro. Op. cit., pp. 57-58; 295; 84-85; 225-226, respectivamente.

${ }^{25}$ MARTINS, Milena Ribeiro. Op. cit., pp. 213-219.

${ }^{26}$ Apud: Idem, p. 255. A integra da nota é a seguinte: "Entra neste livro um punhado de coisas antigas, impressões d'uma mocidade morta que vegetou no ambiente marasmático das cidades mortas. Há também alguma coisa moderna. Mas o antigo como o moderno valem a mesma coisa - nada".

${ }^{27}$ LOBATO, José Bento Monteiro. Cidades mortas. Contos e impressões. São Paulo: Olegário Ribeiro, Lobato \& Cia, 1919, pp. 7-12, citação na p. 7. O acervo da biblioteca da Faculdade de Ciências e Letras, UNESP, Campus de Assis, possui um exemplar da $1^{\text {a }}$ edição, do qual foram retirados os trechos citados.

${ }^{28}$ MARTINS, Milena Ribeiro. Op. cit., pp. 281-282, informa que os textos citados foram retirados já na segunda edição (1920), exceto $A$ poesia e o poeta, que deixou de figurar a partir da $4^{a}$ edição (1923). Pode-se supor que a insistência de Lobato em manter o artigo destoante deveu-se a razões sentimentais, uma vez que o mesmo referia-se a um amigo muito querido, o poeta Ricardo Gonçalves, que se suicidara.

${ }^{29}$ Apud: Idem, p. 263. A autora bem destacou o caráter simbólico de Itaoca, presente nesta nota prefacial.

${ }^{30}$ Vale destacar que na $4^{a}$ edição (1923) o conteúdo do livro foi dividido em dois blocos: coisas mais recentes, reunidas no subtítulo Cidades mortas, e coisas mais antigas, intituladas Literatura no Minarete, pequeno jornal no qual o autor colaborava e que circulou de 1903 a 1907. A tentativa repetiu-se nos Contos leves (1935), volume que enfeixava, ao lado de Cidades mortas, material proveniente de outras obras de Lobato. A ordenação pela cronologia foi abandonada quando da $2^{a}$ edição dos Contos leves (1941) e não mais seria retomada seja na Edição Ônibus (1943), seja nas Obras Completas (1946).

${ }^{31}$ No texto Oblivion, o autor assim se refere aos seus habitantes: "Esses, todos os dias, fazem as mesmas coisas, dormem o mesmo sono, sonham os mesmos sonhos, comem as mesmas comidas, comentam os mesmos assuntos, esperam o correio, gabam a passada prosperidade, lamuriam do presente e pitam - pitam lentos cigarros de palha, matadores do tempo." LOBATO, José Bento Monteiro. Cidades mortas, p. 14.

${ }^{32}$ Idem, p. 23.

${ }^{33}$ Idem, pp. 17-20.

${ }^{34}$ Idem, pp. 22-23.

${ }^{35}$ Ver o conto Cavalinhos, Idem, pp. 40-45, no qual o personagem Lauro já não mais se encanta com o circo, que tanto o apaixonara. Sobressai a desilusão diante de um futuro sem perspectivas, que se apresenta como mera repetição do passado.

${ }^{36}$ Antes da edição de 1935 o conto Júri na roça intitulava-se $O$ caso do tombo. A respeito do debate, bastante forte na época, entre o direito clássico e o positivo consultar: FERLA, Luis Coelho. Feios, sujos e malvados sob medida. Tese (doutorado em História). São Paulo: USP, Faculdade de Filosofia Letras e Ciências Humanas, 2005.

${ }^{37}$ Idem, pp. 31-32.

${ }^{38}$ Idem, p. 22.

${ }^{39}$ A respeito do sucesso alcançado no Brasil por Paul de Kock e Pouson de Terrail ver: MEYER, Marlyse. Folhetim. Uma história. São Paulo: Companhia das Letras, 1996.

${ }^{40}$ Observe-se a ironia de Lobato na escolha dos pseudônimos, atitude que em si já se constituiu numa verdadeira declaração de princípios.

${ }^{41}$ LAJOLO, Marisa. "Jeca Tatu em três tempos". In: SCHWARZ, Roberto (org.). Op. cit. 